\title{
Commercialisation of theological education as a challenge in the Neo-Pentecostal Charismatic churches
}

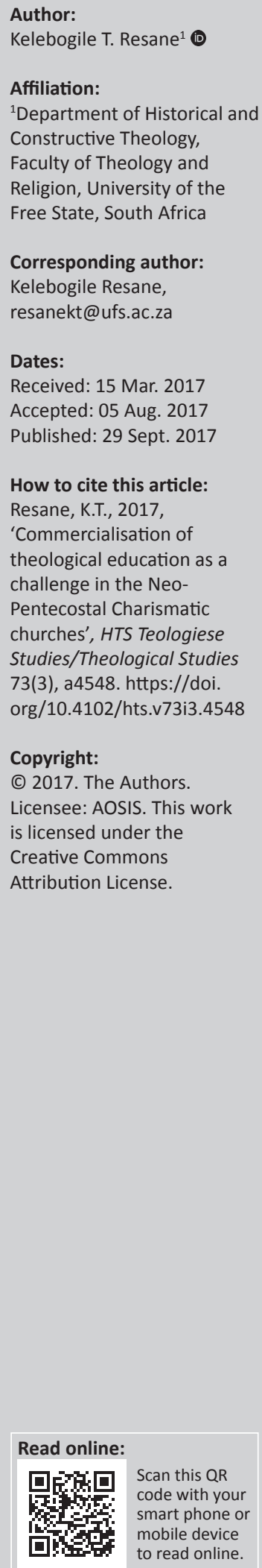

Commercialisation, technology, and globalisation impact all facets of religion. Commercialisation of religion contributes towards society's obsession with success. One area through which commercialisation manifests itself is in theological education. This is exacerbated by the celebrity cult whereby the leader's success is measured by wealthy appearance. The current legal accreditation requirements put pressure on the Neo-Pentecostal Charismatic ministerial formation. The online courses come at a high price, as they also promote the popular literature that is not scholarly insightful. The Neo-Charismatic leaders undermine the formal theological training, since they claim to be taught by the Holy Spirit.

\section{Introduction}

In this article, the Neo-Pentecostal Charismatic churches refer to the 'nondenominational Christianity' (Anderson 2006:157) that emphasises the post-Biblical availability of the gifts of the Spirit. These gifts include speaking in tongues, healing, prophecy, word of knowledge, laying on of hands, etc. These are, however, attained without the prerequisite of the baptism with the Holy Spirit as emphasised in classical Pentecostalism. Burgess and Van der Maas (2002) define these churches as:

Christian bodies with Pentecostal-like experiences that have no traditional Pentecostal or charismatic denominational connections, (and sometimes only very slender - if - any - historical connections. (pp. 286-287)

The nineties was the decade of the mushrooming of independent charismatic churches. Leaders seceded from either classical Pentecostal or mainline denominations. This was the overflow of the phenomenon out of the western world, especially out of the 'prosperity gospel movement' or the so-called 'Toronto blessing'. This was and still accompanied by commercialisation endeavours as this article articulates.

With the emergence of the New Apostolic Reformation championed by Peter Wagner in the US, these churches flourished under the polity coined as 'fivefold ministry' (Eph 4:11):

The movement engages aggressive recruitment of pastors, independent congregations and nondenominational churches by assimilating them through cell group meetings, church planting and rapid cytokinesis. The assimilation processes articulate into the formation or membership into some form of loose network with a tightly knit history that serves as a basis of an informal or unadvertised governmental structure. Through this process, it expects to rapidly overwhelm and dominate the preexisting Christian denominations of the world. (Resane 2016:1)

It should be noted that because most of the leaders of this movement are the educated elite though in non-theological fields, the training they receive embraces what in social psychology of education is known as Bloom's taxonomy. This taxonomy promotes higher forms of thinking in education such as analysing and evaluating. There is always a reference to head (cognitive) referring to knowledge or mental skills. Then heart (affective) referring to attitude or self where growth in feelings or emotional areas is a focus. Then, there is hand (psychomotor), referring to manual or physical skills (Bloom et al. 1956). Neumann explains it further:

Hands can be summarized as the acquisition of relevant theological and biblical knowledge, hands as the competent development of relevant vocational or ministerial skills, and hearts as the development of a social and personal moral vision - a Christian character and spirituality. (in Naidoo 2012:134)

In the Neo-Pentecostal Charismatics' case the biblical statements, principles, passages or ideas are at disposal for this procedural scrutiny, without engaging historical context or hermeneutical principles: 
The biblical data must be accepted as it is. The core of interpretation is literal acceptance of what is written. Nothing must be explained from the metaphysical stance. This implies that all theoretical knowledge, assumptions, and beliefs should be put aside to allow the biblical data (phenomenon) to speak for itself and reveal its ultimate essence. (Resane 2016:6)

There is nothing wrong with this taxonomy, as it is still widely used in educational fields. However, with commercialisation of theological education, this disregards the fundamental principles of ministerial formation because monetary gain is the focus rather than real impartation of ministerial development. This explains the rationale behind the commercialisation and simplicity of these courses offered online. It should be understood that even in theological education:

Quality teaching requires developing a nuanced understanding of the complex relationships between technology, content, and pedagogy, and using this understanding to develop appropriate, context-specific strategies and representations. (Mishra \& Koehler 2006:1029)

The publicity through diverse media, especially television, internet and radio attracts naive subscribers at the exorbitant prices.

\section{What is commercialisation of theological education?}

Commercialisation of theology is broadly defined in what, how and why the Christian ministry is undertaken. McQuilkin (1988:358-362) refers to this as the unscrupulous methods of gaining funds through common deception, 'bait and switch', psychological manipulation and or asking money in exchange of any item that may bring charm, luck or success of any sort. Gitonga (2011) also affirms this:

Commercialization of the Gospel could be defined as presentation of the Biblical message either as a commodity for sale for material gain or as an object of investment for personal aggrandizement. The former refers to the sale of spiritual benefits, such as spiritual healing and offer of prayers for special needs. The latter refers to the donation of money or item(s) to the Church with an expectation that God will repay much more in return. (p. 320)

These commercial endeavours are mostly undertaken through technology, which is exerting its influence in the evangelical world, especially from the USA and the western world in general. Since the middle of the twentieth century, evangelism through technology had occupied the centrestage of faith propagation. It was popularised by television evangelists such as Billy Graham, Kenneth Copeland, Oral Roberts, Kenneth Hagin, etc. White (1983) gives a vivid picture of this era and phenomenon:

This period saw the advance of radio and television, air transportation, mass communication, accelerated publication of books and other materials, all of which influenced people in new ways. Charles Fuller's 'The Old Fashioned Revival Hour' paved the way for thousands of radio preachers and subsequent television preachers. (p. 52)
Currently, there are TV channels running for 24 hours, and programmes always concluding with an appeal for financial contributions. The kind of appeals accelerates promised confidence, charm and charisma with some physical impressiveness. American preacher Wiersbe (1991:100) points out that the electronic church is a bad use of media, distorts the church, misleads with advertising and propagates bad evangelism. The baby should not be thrown out with a bucket of water. Great caution made by the English theologian Ted Peters (2000:28) should be heeded: 'Many people have gone ahead and thrown out the golden truth along with the idolatrous dross'. For instance, the television and the Internet, in general, is utilised for gospel propagation in some hostile countries in the Middle East and elsewhere.

The alternative is possible to situate technology where it belongs - a tool rather than a god. Parsley (2007:159) cautions that 'We have replaced holiness with humanistic sentiment. We've offered self-help rather than unapologetic calls to selfsacrifice'.

Commercialisation, technology and globalisation affect all facets of religion and faith through diverse means and channels intrinsically. Not only Christianity is impacted but also all religions:

Global communications (radio, TV, internet, and newspapers) can confront every adherent of each religion with all the other religions of the world, whereas 100 years ago the vast majority of the world's population had little contact with the message of another religion. (Schirrmacher \& Johnson 2010:32)

Commercialisation of religion contributes hugely towards society's obsession with success. Numbers and décor of both the auditoria and the preachers, known as tele-evangelists, measure success. This is visible from the pews to the pulpit. Neo-Pentecostal Charismatic tradition is swept and scooped by this. Erickson (1993) expresses this:

The philosophy of the megachurch seems to be that big is beautiful. The disregard for the ministry of small neighbouring churches, the well-polished image of the pastor as a corporate executive and superstar, the quality and breadth of the programing all contributes to the 'winner' syndrome. (p. 204)

All these colourful visuals are technology initiated and implemented. They assign success to the church and or its leader. More funds are spent on lighting, stage décor, architectural design and reception parlour. All these are designed to attract and make the congregants happy and comfortable. The Pentecostal and Charismatic leaders of today are coerced into these, because their success is measured by these very practices. The number, the glitter, the décor and the preacher all lead to encapsulated delusion. Parsley (2007:205) highlights that 'the church in our nation is, on the whole, self-absorbed, pleasure-driven, and comfort-seeking'.

\section{South African situation}

The pre-1994 Christianity of South Africa was diversified regarding theological training and ministerial formation. Just 
as society was racially divided, so was educational field in all its formulations. The three racial groups (black people, white people and mixed race or Indians) trained theologically according to their ecclesiastical traditions that were also racially segregated. Races of the same denominations could not train together in one campus, and their curricular were not the same. The admission requirements were inequitable as per dictates of the national education policy of the time.

This scenario inevitably allowed proliferation of ministerial training and formation in different churches. Standards were unequal and diverse. The forbears of the Neo-Pentecostal Charismatic churches (Classical Pentecostals) were not left unscathed. Wherever these denominations existed, designations were along the racial bars. In reference to Apostolic Faith Mission (AFM), Nel (2014) points out:

Racial segregation determined the social fabric of the South African community and the fact that the Bible schools of the AFM were racially divided was the logical result of the political policy that the Church accepted unquestionably as part of its functioning. (p. 113)

The Neo-Pentecostal Charismatics in attempts to balance their divine calling with authentic ministerial training, especially from the 1990s, embraced commercialised courses, for obvious reasons such as the nature of these courses' shortterm, simplicity, popularity and accessibility through the Internet.

The new government of South Africa tightened the screws regarding education and training, and this affected theological training, as many institutions could not match up the requirements. For instance, Notice No. 16 of 2006 on Further Education and Training Colleges Act stipulates requirements that included the qualifications of trainers, facilities of training, culturally relevant curriculum, resources available and accessible for and by students. This entails sustainability of the institutions including record keeping, finances, corporate governance and controls that ensure accountability to the Department of Higher Education and Training.

Recently, the Minister of Higher Education and Training, Dr Blade Nzimande (Skills Portals August 2014), condemned some electronic institutions in South Africa for conferring some degrees with questionable names and titles. Some Charismatic pastors had been selling honorary degrees to some naïve pastors and artists. This is all based on commercial gains in the name of religion:

Most of the pastoral agents conferring these degrees are always on a media spotlights for these activities. Good examples include the likes of Bishop Keith Hurrington, who according to the Sunday World Newspaper (2012) claims some association with a fictitious institution by the name of International Theological Seminary of California, U.S.A (ITSC). The same newspaper reports that Hurrington has allegedly been awarding honorary doctorates under the same institution, collecting between R3000 and R6000 from prospective honorary recipients. Another example to be cited is that of Archbishop Prof. Emanuel Ketsekile of the unknown and non-accredited Emmanuel Christian University. He has been conferring honorary doctorates to many naïve pastors in and around the Free State Province, and other territories. (Resane 2017:3)

The current South African government initiative through its Commission for the Promotion and Protection of the Rights of Cultural, Religious and Linguistic Communities (CRL Rights Commission) has caused an uproar within some Christian circles. It aims to investigate and look into the commercialisation of religion and the abuse and exploitation of people's belief systems. The Commission Chairperson, Thoko Mkhwanazi-Xaluva, was quoted:

When churches start selling pap, T-shirts and water after services ... or when people stop taking their HIV or blood pressure medicine because traditional healers say 'drink my water, it will heal you', and charge people for it, it becomes problematic. (21 August 2015, Cape Times)

In its final report, the commission, in one of its findings (Mkhwanazi-Xaluva 2016: 25) claims that there is a prima facie evidence of commercialisation of religion. It states:

1. People are expected to part with lots and lots of money before blessings and prayers could be said over them.

2. Blessed water and oils are sold to congregants at a high marked up price.

3. Access to the spiritual leader or traditional healer is only guaranteed by payment of a fixed amount of money.

4. T-shirts, towels and Vaseline are sold to congregants for good luck.

5. Banks speed points are used for people to swipe their bankcards during ceremonies.

Commercialisation of theology or religion has become a reality that leaves Christianity with numerous tainted images that question its credibility and sanctity. The report clearly shows that among some Pentecostal or Charismatic groupings, the personality cult (dominance, if not worship of the pastor) is not just manifested in or through kerygma, but also in financial transactions and management. It was discovered that these groups flout the banking rules. The report (Mkhwanazi-Xaluva 2016:26) continues that:

1. In some cases, money collected from the members is never banked with any commercial bank.

2. In some cases, where banking is happening, the money is banked not into the institution's account but the spiritual leader's account, thereby becoming both the pastor and treasurer.

3. Lack of fiduciary committees such as finance, internal audit and financial management.

\section{How commercialisation manifests itself}

It is observed that the Pentecostals, especially the NeoCharismatics, are critical to what they call the 'current maladies of theological seminaries' (Wagner 1999:234). For them, the local church occupies the centre stage of ordaining 
the new pastors or church workers. The church staff members are home grown, trained in conferences and are local church DNA compliant. The popular literature plays an important role as ideal references for core curriculum. Books, DVDs, videos and manuals appeal to ministerial formation programmes. The message is spread both in secular and religious media:

Opening the normal newspaper, web page, or a magazine, a reader is bombarded with some appealing adverts of earning degrees online. There is a proliferation of institutions the world over, offering qualifications online. The e-books and e-study guides downloadable online have eclipsed in a recent past. The emerging e-assessment methods make the situation larger than can be stated. The advent of skype and chat lines in the social media world are subliminally corroding, lessening, and eliminating the need and importance of the physical structure of the university. (Resane 2015:4)

The matter of concern is commercialisation of the theological education. It is true that 'Rational self-interest governs our religious economy, a religious marketplace of products and services' (Hunsberger in Stackhouse 2003:123). This tendency is also observed by Martin (2016) that:

the proliferation of popular books, ministry training materials, and internet resources make information readily available to everyone; therefore, formal education is not considered essential. (p. 3)

The celebrity cult is the first manifestation, whereby success is used as a measure of spirituality. In some Charismatic circles, commercialisation focuses on a personality:

South Africa's fast-growing religion is celebrity worship. From gossip magazines to entertainment TV, from blogs to adverts featuring famous faces, the stars; including pastors, prophets, apostles etc., are the new gods and goddesses. The Christian community is so quick to put them on pedestals; even more enthralled when they traverse and reverse the foundations of the Christian dogma. (Resane 2017:3)

Celebrity cult in this context refers to the elevation of a leader to some high status of beauty, achievement, prestige and power. The Christian community is subtly and subliminally expected to blindly promote and embrace this personality or character. The success is based on properties such as auditorium, vehicles and personal adornment such as tailor-made outfits, jewellery, etc. The number of followers further enhances this appearance, and the leisure the leader enjoys because of contributions given by congregants. It is unfortunate that the Charismatic believers attach a 'high' or 'divine' regard for their leaders, especially the leaders of the megachurches. The followers unreservedly embrace the fact that:

As spiritual and social authority is vested in his person, the religious leader becomes representative of a divine being whose will is that of God and whose actions are above reproach. (Shupe, Stacey \& Darnell 2000:114)

Ironically, these same megachurch pastors are 'better educated than smaller church counterparts', with most of them holding either masters or doctoral degrees (Bird \&
Thumma 2011:11). Utilisation of technology raises the profile and the ego of most of the Charismatic preachers. Authenticity is attached to these external appearances, including the wider media coverage:

To be authentic, the pastor must perform miracles and undergo some kind of a test, from tax problems to other legal challenges. His sermons must be able to induce hysteria and hold the audience spellbound for hours. He must speak to the lack of work, love and luck. The acoustics must be of the right kind too. A little help from technology hastens the process of belief. (Mngxitama 2016)

The second manifestation of commercialisation of the gospel in Neo-Pentecostal Charismatic tradition is the lack of accreditation of their qualifications. Prior to democracy in 1994, theological education was left to denominational groups for ministerial training and formation. Regardless of the government's current requirements for accreditation, some Pentecostal-Charismatic groups continue to offer some pastoral training. This has, to a certain degree, opened the door for commercialisation of theological training. Many underqualified church leaders undertake some training that are not up to the standard and ask for high monetary costs for these courses. History of the birth of this movement carries some bearing for this approach. For instance, Wagner (1999:235), the American missionary ecclesiologist known for championing the Charismatic ecclesiology that he calls New Apostolic Reformation, labels the theological scholarship the tombstone markers. According to him, the New Apostolic Reformation curriculum brings forth a new impartation, not information. He argues that the curriculum and the institution should impart life, vision and anointing to students. This conception is not wrong, but needs to be evaluated carefully. There is no doubt that, "The work of faith and the work of reason both form the believer, and both are the focus of theological education' (Dunsmuir \& McCoy in Naidoo 2015:30).

Neo-Pentecostal Charismatic theology, if any, is not on any formulation of dogma, but on experience. Neumann (in Naidoo 2012:135) rightly points out that 'Pentecostals tended to emphasise worship, evangelism and Christian service rather than focusing on theological issues'. It is also observed that the colleges run by the Charismatic groups lack a content that can challenge their graduates to enter the professional higher learning of matters of faith. Passion for service precedes knowledge. This is also clearly pointed out by Warrington (2008):

For most of its existence, Pentecostal Theological Colleges have been the venues for short-term preparation for ministry, not places for exploration and contemplation. Studies were not expected to last for longer than 2 years and were often much shorter, the teachers often being successful or experienced ministers or evangelists. Neither has all the teaching been of a high academic calibre nor was intended to provide an opportunity for discourse or analysis. (p. 152)

The third manifestation of commercialisation of theology in Neo-Pentecostal Charismatic traditions is the tendency 
towards online courses. Because the Internet had become fast in the developing countries such as South Africa, the NeoPentecostal Charismatics embrace and prefer short cuts into academia, hence falling for online courses that make one to complete a Bachelor or Master's degrees within weeks. These offer qualifications that lack theological insight and depth. It inevitably breeds the lack of clarity in ecclesiological undertakings such as structure, polity and conduct. Through technological invents, Pentecostals and Charismatics embrace what Parsley (2007) refers to as:

Convenience, not commitment, has become paramount. Selfhelp books fly out of retailers' displays and become best-sellers, while those that require self-examination or even careful thought gather dust on the shelves. You don't sell many books with themes such as 'How to be crucified with Christ'. We have an insatiable appetite for 'self-help', and little stomach for selfdenial. (p. 206)

These courses divorce them from active participation in academic activities of theological field. Warrington (2008) says:

This propensity is often most espoused where Pentecostal leaders are less educated as well as where the perception of ministerial success is viewed as being solely or significantly due to the Spirit. (p. 154)

Should they move from this caveat their involvement in research and productive work will establish a vital link to dialogue with the broader theological dictum? The kind of education they need to engage in is the one that gains purpose and significance to the extent it is consistent with and contributes towards accomplishment of God's highest purpose for humanity. John MacArthur (2003:245) refers to it as the one that 'assist individuals in developing the knowledge, skills, and attitudes that will enable them to better glorify and enjoy God'.

The current accreditation processes of the South African government opened the door for private short learning programmes. These do not come cheap, and prices are always exorbitant. Many took the advantage to commercialise theological education through these short learning programmes. Some pseudonymous institutions pretended to be offering these government's accredited programmes. Some leaders and artists are conned into paying these high prices. For instance, Skillsportals in 2014 captured this:

The Department of Higher Education and Training has learnt with dismay the reported story in Sowetan on counterfeit Doctoral degrees to Mr Bheki and Linah Ngcobo who are also the known South African Maskandi musicians, by a University operating illegally in Johannesburg and not accredited on Programmes offerings.

The department affirms that this university called Anointed University owned by Nigerian nationals (Mr George Aladeoba and his wife) is an illegal university, it is not accredited and with no registration number. Their Programmes are therefore not recognised.

The fourth common manifestation is the biblical reference of claiming to be taught by the Spirit. Woodbridge and McComiskey (1991) capture this sentiment accurately:
The pneumatological penchant of Pentecostals is well-known: their constant reliance on the Holy Spirit, who would teach them all things in Jesus' absence, who would facilitate 'greater works' than Jesus himself performed, who would grant a 'word of knowledge' understood as divinely originated disclosures of hidden information, and whose empowerment would result in accompanying signs (Mark 16:17). The Johannine reminder (1 John 2:27) 'you do not need anyone to teach you' is often cited among Pentecostals to obviate academic study. (p. 302)

This is because that as far as they are concerned 'the Spirit makes and equips teachers, is an active participant in their development and is the one who enables them to change in a changing world' (Anderson 2006:249).

The argument here is that the lack of proper theological education makes church leaders to be gullible to inadequate doctrinal focus. Technology in a form of online courses that lack in depth makes inroads into the naïve pastoral figures who end up commercialising religion for personal gains. The online courses or self-help materials do not develop critical thinking as the readers absorb contents without any sifting to validate the texts or ideas expressed. The tendency here is that incumbents become hero-worshippers instead of mentees or protégés who pursue theological knowledge and character formation that is consonant with the minister of the gospel. This is pointed out by Martin (2016) that:

Many ministers choose to learn by observing other ministers who appear to be successful. Training seminars and pastors' conferences that are offered by megachurch pastors have become a substitute for college and seminary. (p. 3)

This scenario is open to copying the wrong traits and practices, as the leader who is defined by behavioural scientist Weber (1978:241) as having 'supernatural, superhuman, or at least specifically exceptional powers or qualities' but can consequently be a wrong model to imitate.

\section{Conclusion}

The bottom line is that technology has significantly enhanced commercialisation of religion. This was mostly through the electronic church from the western world, especially the USA. The latest development of applying technology in teaching theology made some strides in media advertisement of courses offered online. Though there is nothing wrong with using technology in promoting some theological training, the question that remains is the quality and the depth of the content offered.

The Neo-Pentecostal Charismatics had for decades become victims of the sub-standard and unaccredited online courses. The advertisements make it look good, to a certain degree to be true. It is of supreme importance to promote to these churches the importance of formal theological training that is enthused and enhanced by human interaction elements. Kretzschmar (2011) points this reality out:

In a residential seminary or theological college, it is much easier to promote the integration of life and studies. The classroom context, the tutorial system and all the other activities within a 
residential college, such as times of worship, informal conversations, joint meals and playing sport, are crucial to the broad 'formation' of the students. In smaller, well-staffed colleges, staff members and senior students both tutor and mentor students in terms of their academic performance, the development of their character and their ability to live in community. Support and/or counselling are easier to offer when students face family or other problems. In such a setting, the aim is not just to get a degree, but to develop a spirituality that will nurture and challenge each student. (p. 63)

Technology should not be selectively used for commercialisation of theology, but for sharpening people for ministry skills. Learning theology in the most appropriate channels can revolutionise Neo-Pentecostal Charismatics in a very significant way. Theology is unique in ministerial formation:

It is a living science where the soul of the tutor and that of the student, must somehow connect. Since it is a science that shapes the thoughts and character, interaction is vital. Much of theological education is concerned with helping people know what their tutors know and are. As a social science, theology is not just the facts transmission, but promotive interaction whereby individuals encourage and facilitate each other's efforts towards the task and achievement of learning goals. As part of education, it galvanizes both the tutors and the students towards learning for character formation. (Resane 2015:5)

On the other hand, technology is there to serve humanity in the most honourable way. It is a tool designed to expedite and facilitate maximum teaching and learning. There is no way the church, even the Neo-Pentecostal Charismatics, can marginalise technology, lest it dissect the worldview into two natural worlds - a human tendency that might be dangerous as it privatises faith. Kretzschmar (1997) cautions this elsewhere:

A privatised faith is based on a dualism which separates reality into different spheres: the physical and the spiritual; the secular and the sacred; the public and the private; the saving of souls and social involvement. Personal religious transformation is encouraged but the application of religion to social structures is frowned upon. (p. 313)

Although this is a tendency among the Pentecostals and Charismatics, it is vital for them to be alerted of this danger, which might exclude technology or abuse it for commercial purposes under the cloak of 'preaching' or 'ministering'. The appeal to the mainstream Christianity is to collaborate with Neo-Pentecostal Charismatics to facilitate a genuine, relevant and quality theological education that will produce technologically elite pastors who will handle technology honourably:

The kind of education they need to engage in is the one that gains purpose and significance to the extent it is consistent with and contributes toward accomplishment of God's highest purpose for humanity ... This education emphasises the knowledge, change of heart or attitudes, and equips one with skills to handle issues in life honourably. However, it is to be acknowledged that these leaders are excited and enthusiastic about their faith and evangelism in the world. (Resane 2017:11)
Commercialisation of theology or religion poses an enormous challenge to the faith community, and it must be continually scrutinised and researched. The ecclesial formations should take into consideration the fact that:

[T]he church should intentionally become a public space for deliberation, criticism, cultural comprehension of technology in all its manifestations, powers, impotencies, promises, and dangers. (Cole-Turner in Stackhouse 2000:110)

Regardless of the commercialisation of theological education embraced by Neo-Pentecostal Charismatic movement theologies, the central attitude and approach should be that of integrity. There is no doubt that Pentecostal and Charismatic brand of Christianity is blemished with struggles in the areas of accountability, morality and leadership lifestyle. Time has arrived for effective ministry through technology, not for commercial gain, but for the expansion of the kingdom of God. Self-help must be replaced with selfsacrifice in all attempts of faith propagation and incarnation.

The appeal for integrity is to draw back to the centre and the essence of the church gathering and worshipping. The gathering church should enjoy living in the light of the triune God. This truth is expressed by Dearborn that:

Living with greater expectation and openness for God to speak and act in the midst of our ecclesial gathering would reflect our belief that God is present. This would mean resisting the pressure to create highly structured performances as worship services, after a model of television or radio show. It would also mean valuing smaller and less formal gatherings. (in Stackhouse 2003:68)

Commercialisation of theological education in South Africa and the world at large is a concern in Christendom. It misplaces the resources and paints the Christian faith negatively. It should be continuously discussed as a way of raising awareness for the sake of the naïve people out there deserving to receive quality ministerial formation and theological education that is accredited.

\section{Acknowledgements Competing interests}

The author declares that he has no financial or personal relationships which may have inappropriately influenced him in writing this article.

\section{References}

Anderson, A., 2006, An introduction to Pentecostalism, Cambridge University Press, Cambridge.

Bird, W. \& Thumma, S., 2011, 'A new decade of megachurches: 2011 profile of large attendance churches in the United States', viewed 21 June 2017, from http://hirr. hartsem.edu/megachurch/New-Decade-of-Megachurches-2011Profile.pdf

Bloom, B.S. (ed.), Engelhart, M.D., Furst, E.J., Hill, W.H. \& Krathwohl, D.R., 1956 Taxonomy of educational objectives, handbook I: The cognitive domain, David McKay Co Inc., New York.

Burgess, S.M. \& Van der Maas, E.M. (eds.), 2002, 'Neocharismatics', in The New International Dictionary of Pentecostal and Charismatic Movements, pp. 473-475, Zondervan Publishers, Grand Rapids, MI.

Cole-Turner, R., 2000, 'Science, technology, and mission', in M.L. Stackhouse, T. Dearborn \& S. Paeth (eds.), The local church in a global era: Reflections for a new century, pp. $100-112$, W.B. Eerdmans Publishing Company, Grand Rapids, MI. 
Dearborn, K.L., 2003, 'Recovering a Trinitarian and sacramental ecclesiology', in J.G. Stackhouse (ed.), Evangelical ecclesiology: Reality or illusion?, pp. 39-73 Baker Academic Books, Grand Rapids, MI.

Dunsmuir, C. \& McCoy, M., 2015, 'Accreditation and ministerial formation: Serving two masters', in M. Naidoo (ed.), Contested issues in training ministers in South Africa, pp. 27-41, SunMedia, Stellenbosch.

Erickson, M.J., 1993, The evangelical mind and heart: Perspectives on theological and practical issues, Baker Book House, Grand Rapids, MI.

Gitonga, N., 2011, 'Commercialization of the Gospel in Africa with particular reference to Kenya: A critique', Kenya Methodist University, vol. 2(2), viewed 17 August 2016, from http://www.kemu.ac.ke/new/index.php/ijpp/volumesand-issues/131research/ijpp/volume-2/v2-issue2/320-commercialization-ofthe-gospel-in-africa

Hunsberger, G.R., 2003, 'Evangelical conversion toward a missional ecclesiology', in J.G. Stackhouse (ed.), Evangelical ecclesiology: Reality or illusion?, pp. 105-132, Baker Academic Books, Grand Rapids, MI.

Kretzschmar, L., 1997, 'The gap between belief and action: Why is it that Christians do not practise what they preach?', Scriptura 62, 311-321. https://doi.org/10.7833/ 62-0-624

Kretzschmar, L., 2011, 'Can morality be taught? A reflection on teaching theological ethics at a tertiary level in the Unisa Open and Distance Learning Model', Journal of Theology for Southern Africa 141, 61-80.

MacArthur, J., 2003, Think biblically: Recovering a Christian worldview, Crossway Books, Wheaton.

Martin, L.R., 2016, 'You shall love the Lord...with all your mind': The necessity of an educated Pentecostal clergy', Pharos Journal of Theology 97, viewed 22 Novembe 2016, from http://www.pharosjot.com

McQuilkin, R., 1988, An introduction to biblical ethics, Columbia Bible College and Seminary (Class Notes for Biblical Ethics), Columbia, SC.

Mishra, P. \& Koehler, M., 2006, 'Technological pedagogical content knowledge: A framework for teacher knowledge', Teachers College Record 108(6), 1017-1054. https://doi.org/10.1111/j.1467-9620.2006.00684.x

Mkhwanazi-Xaluva, T., 2016, CRL Rights Commissions Report of the Hearings on Commercialisation of Religion and Abuse of People's Belief Systems, Commission for the Promotion and Protection of the Rights of Cultural, Religious and Linguistic Communities, Braamfontein.

Mngxitama, A., 2016, 'Politicians and pastors preach a false gospel', Mail \& Guardian 24 March, viewed 22 August 2016, from http://mg.co.za/article/2016-03-23politicians-and-pastors-preach-a-false-gospel
Nel, M., 2014, 'A hundred years of theological training in the apostolic faith mission of South Africa', Acta Theologica 34(1), 108-126. https://doi.org/10.4314/actat. v34i1.7

Neumann, M., 2012, 'Ministerial formation in the Charismatic context: Heads, hearts and hands', in M. Naidoo (ed.), Between the real and the ideal: Ministerial formation in South African churches, pp. 133-145, UNISA Press, Pretoria.

Parsley, R., 2007, Culturally incorrect: How clashing worldviews affect your future, Thomas Nelson, Nashville.

Peters, T., 2000, God - The world's future: Systematic theology for a new era, 2nd edn., Fortress Press, Minneapolis, MN

Resane, K.T., 2015, 'Challenges for teaching theology through technology in institutions of higher learning', Pharos Journal of Theology 96, viewed 23 November 2016, from http://www.pharosjot.com

Resane, K.T., 2016, 'The new apostolic reformation: The critical reflections of the ecclesiology of Charles Peter Wagner', HTS Teologiese Studies/Theological Studies 72(3), a3240. https://doi.org/10.4102/hts.v72i3.3240

Resane, K.T., 2017, 'And they shall make you eat grass like oxen, (Daniel 4:24): Reflections on recent practices in some new charismatic churches', Pharos Journal of Theology 98, viewed 16 March 2017, from http://www.pharosjot.com

Schirrmacher, T. \& Johnson, T.K., 2010, 'Why evangelicals need a code of ethics for mission', International Journal for Religious Freedom 3(1), 23-37.

Shupe, A., Stacey, W.A. \& Darnell, S.E., 2000, Bad pastors: Clergy misconduct in Modern America, New York University Press, New York.

'The Skillsportal: Skill for success', Nzimande condemns illegal university in JHB, Monday, 11 August, viewed 19 December 2016, from http://www.skillsportal. co.za/content/nzimande-condemns-illegal-university-jhb

Wagner, C.P., 1999, Churchquake! Regal Books, Ventura.

Warrington, K., 2008, Pentecostal theology: A theology of encounter, T \& T Clark, London.

Weber, M., 1978, Max weber economy and society, University of California Press, Berkeley, CA.

White, J., 1983, The church and the Parachurch: An uneasy marriage, Multnomah Press, Portland.

Wiersbe, W.W., 1991, The integrity crisis, Expanded Edition with Study Guide, Oliver Nelson Publishers, Nashville.

Woodbridge, J.D. \& McComiskey, T.E., 1991, Doing theology in today's world: Essays in honor of Kenneth S Kantzer, Zondervan Publishing House, Grand Rapids, MI. 